\title{
A Review of Medicinal Uses and Pharmacological Activities of Tridax Procumbens (L.)
}

\author{
Samantha Beck ${ }^{1}$, Heather Mathison ${ }^{1}$, Toma Todorov ${ }^{1}$, Esli-Armando Calderón-Juárez ${ }^{2}$ \& Olga R. Kopp ${ }^{1}$ \\ ${ }^{1}$ Department of Biology, Utah Valley University, USA \\ ${ }^{2}$ Instituto Guatemalteco de Seguridad Social, IGSS, Guatemala \\ Correspondence: Olga R. Kopp, Department of Biology, Utah Valley University, USA. E-mail: koppol@uvu.edu
}

Received: September 8, 2017

doi:10.5539/jps.v7n1p19

\author{
Accepted: September 22, 2017 Online Published: January 28, 2018 \\ URL: https://doi.org/10.5539/jps.v7n1p19
}

\begin{abstract}
Tridax procumbens is a very promising species that produces secondary metabolites reported to have a variety of medicinal uses including among others, anti-anemic, anti-inflammatory, anti-diabetic and anesthetic properties. This species has a long history of traditional use by different communities. This study aimed to review the scientific literature regarding the medicinal properties, biological activity and phytochemical components of $T$. procumbens, a member of the Asteraceae family that originated in Central and South America. An extensive literature review was done using Metadatabase EDS, MedLine (PubMed), Science Direct, Web of Science, Academic Search Premier, Scielo, DOAJ Directory of Open Access Journals, JSTOR, and other sources to find information relevant to the medicinal uses of $T$. procumbens. At total of 130 studies were found that contained information about $T$. procumbens. Some of the papers were not included because of the relevance to this study, ending with a total of 111 relevant citations reported here. This review shows the importance of more studies to understand the potential of $T$. procumbens' secondary metabolites for medicinal or preventive treatment, making it a promising ethnobotanical resource. This review provides important information of this species and indicates that this species could be an effective, safe and affordable treatment for some ailments, especially in tropical areas where this plant is native and widely distributed.
\end{abstract}

Keywords: Tridax procumbens, anti-inflammatory, anti-diabetic, immunomodulatory, antimicrobial, hepatoprotection, anti-hypertensive

\section{Introduction}

Tridax procumbens, also known as "coat buttons" is a perennial plant from the Asteraceae family, native to Central and South America (Hilliard, 1977; Ravikumar et al., 2005b). Since ancient times, this species has been used in Ayurveda in India (Kethamakka and Deogade, 2014). Different substances such as oils, teas and skin poultices, among others, have been manufactured using this species (Foret, 2012). T. procumbens has diverse pharmacological properties including but not limited to: immunomodulatory, anti-oxidant, anti-hepatotoxic, analgesic, antidiabetic, anti-inflammatory, antifungal, and antimicrobial activities. (Ravikumar et al., 2005a; Ravikumar et al., 2005b; Bhagwat et al., 2008; Sawant et al., 2014; Hitesh, 2006). The versatility of the species is most likely due to the plant's defense mechanisms, secondary metabolites such as flavonoids, alkaloids, tannins, carotenoids and saponins. The aim of this review is to highlight the importance of this species as a valuable medicinal plant. The connection of the traditional and scientific knowledge is important for future studies.

\subsection{Botanical Description}

Tridax procumbens (family Asteraceae) is known by different names throughout the world (Table 1). 
Table 1. Common names of T. procumbens found throughout the world.

\begin{tabular}{|c|c|c|}
\hline Country/ Language & Vernacular Names & Source \\
\hline Chinese & Kotobukigiku & Ankita and Jain 2012 \\
\hline English & Coat buttons, Tridax daisy & $\begin{array}{l}\text { USDA, Ankita and Jain 2012, Kumar et al., 2012; } \\
\text { Chauhan and Johnson, 2008; Ravikumar et al., 2005b, } \\
\text { Bhagwat et al., 2008. }\end{array}$ \\
\hline French & Herbe Caille & Ankita and Jain 2012 \\
\hline Latin & Tridax procumbens (Linn.) & Ankita and Jain 2012 \\
\hline Malayalam & Chiravanak & Ankita and Jain 2012 \\
\hline Marathi & Dagadi Pala & Ankita and Jain 2012 \\
\hline Oriya & Bishalya Karani & Ankita and Jain 2012 \\
\hline Sanskrit & Jayanti Veda & Ankita and Jain 2012 \\
\hline Spanish & Cadillo, Chisaca & ITIS, ND, Ankita and Jain 2012 \\
\hline Telugu & Gaddi Chemanthi & Ankita and Jain 2012 \\
\hline Tamil & Thata poodu & Ankita and Jain 2012 \\
\hline Australia & Tridax daisy & Holm et al., 1997 \\
\hline Brazil & Erva de Touro & Holm et al., 1997 \\
\hline Burma & Mive Sok Ne-gya & Holm et al., 1997 \\
\hline Burundi & Agatabi & Byavu et al., 2000 \\
\hline Colombia & Cadillo Chisaca & Holm et al., 1997 \\
\hline Cuba & Romerillo de Loma, Romerillo & Holm et al., 1997 \\
\hline Dominican Republic & Piquant Jambe & Holm et al., 1997 \\
\hline El Salvador & Hierba del Toro & Holm et al., 1997 \\
\hline Fiji & Wild Daisy & Holm et al., 1997 \\
\hline Ghana & White-dirty Cream, Nantwi bini & Holm et al., 1997; Komlaga et al., 2015 \\
\hline Guatemala & Bull Grass, Bull's herb & Vibrans 2009, Gamboa-Leon et al., 2014 \\
\hline Hawaii & Tridax & Holm et al., 1997 \\
\hline Honduras & Hierba del Toro & Holm et al., 1997 \\
\hline India & $\begin{array}{l}\text { Bisalyakarmi, Mukkuthipoo, Phanafuli, } \\
\text { Tunki, Ghamara, Javanti Veda, Dhaman grass, } \\
\text { Vettukkayapoondu, Vettu kaaya }\end{array}$ & $\begin{array}{l}\text { Holm et al., 1997; Kumar et al., 2012; Kethamakka and } \\
\text { Deogade, 2014; Pareek et al., 2009; Ravikumar et al., } \\
\text { 2005b, Bhagwat et al., 2008, Silambarasan and Ayyanar, } \\
\text { 2015, Yabesh et al., 2014. }\end{array}$ \\
\hline Indonesia & Gletang, Gletangan, Sidowlo, Tar Sentaran & Holm et al., 1997 \\
\hline Jamaica & Bakenbox & Mitchell and Ahmad, 2006 \\
\hline Japan & Kotobukigiku & Holm et al., 1997 \\
\hline Java & Songgolangit & Petchi et al., 2013 \\
\hline Madagascar & Anganiay & Holm et al., 1997 \\
\hline Malaysia & Coat Buttons, Kanching Baju & Holm et al., 1997 \\
\hline Mauritius & Herbe Caille & Holm et al., 1997 \\
\hline Mexico & Flor Amarilla, Panquica, Rosilla, t’ulum & Holm et al., 1997, Gamboa-Leon et al., 2014 \\
\hline Nigeria & $\begin{array}{l}\text { Igbalobe, Muwagun, Muriyam pachila, } \\
\text { Jayanti, Vettukkaaya-thala }\end{array}$ & $\begin{array}{l}\text { Olowokudejo et al., 2008; Soladoye et al., 2013, } \\
\text { Sureshkumar et al., } 2017\end{array}$ \\
\hline Puerto Rico & Tridax & Holm et al., 1997 \\
\hline Taiwan & Kotobuki-giku & Holm et al., 1997 \\
\hline Thailand & Teen Tuk Kae & Holm et al., 1997 \\
\hline Trinidad & Railway Weed & Holm et al., 1997 \\
\hline United States & Tridax daisy & Holm et al., 1997 \\
\hline
\end{tabular}

T. procumbens is found in tropical and subtropical areas of the world growing with annual crops, along roadsides, pastures, fallow land, and waste areas (Holm et al., 1997). The species has a diploid number of 36 (Raghavan and Vinkatusabban, 1941). It has herbaceous, semi-prostrate habit, and can grow anywhere from $15-40 \mathrm{~cm}$ in height. The leaves are elongated, opposite, ovate with serrated margins, hirsute on the abaxial and adaxial sides (Powell, 1965). The inflorescence is a capitulum with three-toothed white ligulate ray florets female and disc inner flowers yellow, tubular, bisexual, with corolla $6 \mathrm{~mm}$ long. The inflorescence results in abundant production of pappus achenes (Chauha and Johnson, 2008), $2 \mathrm{~mm}$ long, obovoid, setaceous, covered with stiff hairs, that can be carried by the wind for long distances, making this species a potential invasive species if not controlled.

T. procumbens is classified as a noxious weed in Alabama, Florida, Minnesota, North and South Carolina and Vermont. It is quarantined in California and Oregon and prohibited in Massachusetts (U. S. Department of 
Agriculture). In Guatemala T. procumbens is a weed that has a wide range of growth and can be found in either dry or damp soil, usually on previously cultivated ground from sea level to $2300 \mathrm{~m}$ (Pöll, 2005).

\section{Traditional Uses}

Traditional and complementary medicine is being increasingly recognized as an integrative approach to health care in many countries (WHO, 2013). The use of plants for medicinal purposes may date back to the Middle Paleolithic age, approximately 60,000 years ago (Solecki, 1975). T. procumbens is found throughout the world (Table 2) and it has been used to treat anemia, colds, inflammation, and hepatopathies in Central America (Taddei and Rosas-Romero, 2000). In Guatemala, T. procumbens is used as an antibacterial, antifungal, and antiviral treatment (Caceres et al., 1998) as well as for vaginitis, stomach pain, diarrhea, mucosal inflammations, and skin infections (Taddei and Rosas-Romero, 2000). The leaf juice is used to treat wounds and stop bleeding (Caceres et al., 1998). A study done in Chiquimula, Guatemala, showed that lactating pregnant women suffering from anemia could reduce their symptoms by using Tridax (Calderón, unpublished results). This species is also used in the treatment of gastrointestinal and respiratory infections, high blood pressure, and diabetes (Pöll, 2005, Giovannini et al., 2016. Pardeshi and Bhiungade, 2016). In Guatemala, the entire plant is used for the treatment of protozoal infections (Caceres et al., 1998; Berger et al., 1998, Martín-Quintal et al., 2009, Gamboa-Leon et al., 2014, Ebiloma et al., 2017), including malaria, leishmaniasis and dysentery. Aqueous extracts of T. procumbens have strong anti-plasmodial activity against chloroquine-resistant $P$. falciparum parasites (Appiah-Opong et al., 2011); it has activity against Trypanosoma brucei, antibacterial and wound-healing properties (Koram et al., 2014, Agyare et al., 2016). Scientific support for several of these traditional uses will be discussed later.

Table 2. Traditional uses and plant preparation

\begin{tabular}{|c|c|c|c|c|}
\hline \multicolumn{2}{|c|}{ Location } & Preparation/extract & Plant ailment uses & References \\
\hline \multirow{3}{*}{\multicolumn{2}{|c|}{ Guatemala }} & Leaves: juice & $\begin{array}{l}\text { Anemia, colds, inflammation, hepatopathies, } \\
\text { vaginitis, stomach pain, diarrhea, mucosal } \\
\text { inflammation, skin infections, bleeding. }\end{array}$ & $\begin{array}{l}\text { Caceres et al., 1998; } \\
\text { Taddei and Rosas-Romero, } 2000\end{array}$ \\
\hline & & $\begin{array}{l}\text { Leaves: poultice, dried infusions } \\
\text { Stems: dried }\end{array}$ & $\begin{array}{l}\text { Reduce inflammation, gastrointestinal and } \\
\text { respiratory infections, high blood pressure, diabetes }\end{array}$ & Pöll, 2005, Giovannini et al., 2016 \\
\hline & & Whole plant: dried & $\begin{array}{l}\text { Protozoal infections, treatment of chronic ulcers } \\
\text { caused by leishmaniasis, gastrointestinal disorders }\end{array}$ & $\begin{array}{l}\text { Berger et al., } 1998 . \\
\text { Martín-Quintal et al., 2009; } \\
\text { Gamboa-Leon et al., } 2014 \\
\text { Ebiloma et al., } 2017\end{array}$ \\
\hline \multicolumn{2}{|l|}{ India } & $\begin{array}{l}\text { Leaves: dried and other herbs } \\
\text { ingested orally, juice }\end{array}$ & $\begin{array}{l}\text { Diabetes, insect repellent, used to treat diarrhea, and } \\
\text { to help check for hemorrhages, as well as hair loss. } \\
\text { Jaundice, healing of wounds, inflammation }\end{array}$ & $\begin{array}{l}\text { Pareek et al., 2009, Policegoudra et } \\
\text { al., 2014; Saraf et al., 1990, Saraf } \\
\text { and Dixit, 1991, Rajendran et al., } \\
\text { 2003, Taddei and Rosas-Romero, } \\
\text { 2000, Yabesth et al., 2014; Pardeshi } \\
\text { and Bhiungade, 2016. }\end{array}$ \\
\hline \multicolumn{2}{|l|}{ Africa } & $\begin{array}{l}\text { Whole plant: blending with other } \\
\text { herbs adding salt and water }\end{array}$ & Treating mastitis in livestock & Byavu et al., 2000 \\
\hline \multirow{5}{*}{ Africa } & \multirow{2}{*}{ Ghana } & $\begin{array}{l}\text { Decoction with Phyllanthus } \\
\text { amarus }\end{array}$ & Anti-malarial, antibacterial, wound-healing & Koram et al., 2014 \\
\hline & & Aqueous extracts & Anti-plasmodial activity & $\begin{array}{l}\text { Appiah-Opong et al., 2011, Komlaga } \\
\text { et al., } 2015\end{array}$ \\
\hline & Nigeria & Whole plant: dried & $\begin{array}{l}\text { Fever, Typhoid fever, cough, back ache, stomach } \\
\text { ache, diarrhea, epilepsy }\end{array}$ & $\begin{array}{l}\text { Soladoye et al., } 2013 \text {. } \\
\text { Mann et al., } 2003\end{array}$ \\
\hline & Benin & Whole plant: dried & Rabbit or livestock feed & $\begin{array}{l}\text { Aboh et al., 2002, Edeoga et al., } \\
2005\end{array}$ \\
\hline & Togo & Leaves: dried & $\begin{array}{l}\text { Dressing wounds, pain, malaria and abdominal and } \\
\text { gastrointestinal mycosis }\end{array}$ & Agban et al., 2013 \\
\hline
\end{tabular}

In Nigeria, the entire plant is used to treat typhoid fever, cough, fever, stomachache, backache, diarrhea and epilepsy (Soladoye et al., 2013; Mann et al., 2003). Farmers in Africa use the plant for treatment of livestock (Byavu et al., 2000); for example, Tridax is used along Vigna parkeri to treat chronic mastitis by grinding both plants, adding salt and water and applying to the udder. Ayyappa Das et al. (2009) studied the antibacterial effect of Tridax against mastitis-causing bacteria and found that the ethanolic extract had significant activity against Staphylococcus aureus. However, there was little or no activity from the aqueous extracts against Streptococcus uberis and Klebsiella penumonia, in comparison with Spathodea campanulata extracts. In Benin, breeders complement the feed of rabbits (Aboh et al., 2002) or other livestock combining with other plants (Edeoga et al., 2005); although rabbits consume it in lower amounts than other fodder (Aboh et al., 2002), probably due to low 
palatability.

In Togo, the fresh, crushed leaves are used for dressing wounds. The decoction of the leaves is used against pain, to treat malaria, and against abdominal and gastrointestinal mycosis (Agban et al., 2013). In India it is known as an insect repellent, used to treat diarrhea, and to help check for hemorrhages. In addition, some reports include the use as a cure for hair loss (Policegoudra et al., 2014; Saraf et al., 1990) and jaundice (Saraf and Dixit, 1991).

A study in Tamilnadu, India, revealed that native inhabitants apply the juice from the leaves for the healing of wounds. The same study also infers that $T$. procumbens is one of the most useful traditional medicinal plants (Rajendran et al., 2003). It has also been shown to have many minerals like calcium, selenium, magnesium, potassium and sodium (Ikewuchi et al., 2009). The people in Udaipur, India, have traditionally ingested powdered T. procumbens leaves, along with other herbs, to treat diabetes (Pareek et al., 2009; Pardeshi and Bhiungade, 2016). The species has shown to be a great source of potassium, which is used for the treatment of cramps and a safe source ingredient for future medicinal uses. These traditional uses (Table 2) demonstrate the potential uses of this plant.

\section{Phytochemistry}

T. procumbens use as a traditional medicine throughout various regions of the world has led to many publications on its phytochemistry (Table 3). The discovery of new bioactive compounds can lead to the development of new drugs for the treatment of various ailments (Fabricant and Farnsworth 2001). Different extraction techniques used to isolate various compounds found in T. procumbens will be discussed.

Table 3. Phytochemicals found in Tridax procumbens

\begin{tabular}{|c|c|c|c|}
\hline Extraction & Compounds/activity & Plant organ & References \\
\hline Aqueous & Antidiabetic compounds & Aerial parts & $\begin{array}{l}\text { Caceres et al., } 1998 \\
\text { Ikewuchi, } 2012 .\end{array}$ \\
\hline Chloroform, Acetone & Tannins,condensed catechic & Leaves & $\begin{array}{l}\text { Sawant and Godhate } \\
2013\end{array}$ \\
\hline $\begin{array}{l}\text { Ethyl acetate, aqueous, } \\
\text { ethanol }\end{array}$ & $\begin{array}{l}\text { Flavonoids, kaempferol, (-)-Epicatechin, Isoquercetin, } \\
\text { and Glucoluteolin }\end{array}$ & $\begin{array}{l}\text { Leaves, Stem, } \\
\text { Root, and Flowers }\end{array}$ & $\begin{array}{l}\text { Kumar et al., 2012; } \\
\text { Harborne, } 1994 .\end{array}$ \\
\hline \multirow[t]{2}{*}{ Aqueous } & Alkaloids, Akuammide and Vaucangine & & \\
\hline & & Leaves. & Ikewuchi 2012. \\
\hline Methanol- dichloromethane & $\begin{array}{l}\text { Bioactive components for antifungal activity against } \\
\text { dermatophytes. }\end{array}$ & Aerial parts. & $\begin{array}{l}\text { Policegoudra et al., } \\
2014 .\end{array}$ \\
\hline Ethanol- acetic acid & $\begin{array}{l}\text { Alkaloids for antimicrobial activity, against human } \\
\text { pathogens, antioxidant, Hepatoprotective }\end{array}$ & Pedicle and buds. & $\begin{array}{l}\text { Jindal and Kumar } \\
\text { 2012. Hemalatha } 2008 .\end{array}$ \\
\hline Petroleum Ether & Antioxidant uses against DPPH. & Dried plants. & Saxena et al., 1977. \\
\hline Distilled Water- ethanol & Immuno-modulatory effects in rats. & Aerial parts. & Tiwari et al., 2004 \\
\hline methanol -n-butanol & $\begin{array}{l}\text { Isolation of antioxidant chemicals, mostly } \\
\text { flavonoids and saponins }\end{array}$ & Dried leaves. & Saxena et al., 2013 \\
\hline methanol-ethyl acetate & $\begin{array}{l}\text { Isolation of antioxidant chemicals for testing: mostly } \\
\text { Flavonoids and saponins. }\end{array}$ & Dried leaves. & Saxena et al., 2013 \\
\hline n-hexane & $\begin{array}{l}\text { Antimicrobial } \quad \text { against } \quad \text { Mycobacterium } \\
\text { smegmatis,Escherichia coli, Salmonella spp. }\end{array}$ & $\begin{array}{l}\text { Flowers and aerial } \\
\text { parts. }\end{array}$ & $\begin{array}{l}\text { Kethamakka and } \\
\text { Deogade, 2014. }\end{array}$ \\
\hline Ethanol & Saponin B-Sitosterol-3-O- $\beta$-D-xylopyranoside. & Flowers & $\begin{array}{l}\text { Saxena and Albert, } \\
2004\end{array}$ \\
\hline Petroleum ether, ethanol & Anti-ulcerogenic effects & Leaves & Jhariya et al., 2015 \\
\hline Hydro-distillation & $\begin{array}{l}\text { Essential oil, anti-microbial and anti-inflammatory } \\
\text { effects. Terpenes, alpha and beta pinenes }\end{array}$ & Leaves. & $\begin{array}{l}\text { Manjamalai et al., } \\
2012 \mathrm{~b}\end{array}$ \\
\hline Ethanolic extract & Phytochemical screening: alkaloids, glycosides & Whole plant dried. & $\begin{array}{l}\text { Kamble and Dahake, } \\
2015\end{array}$ \\
\hline
\end{tabular}

\subsection{Phytochemical Screening}

Many studies have been done on the phytochemistry of Tridax, given the potential of this species (Tables 3 and 4), resulting in a variety of compounds. For example, anthraquinones, anthrones, flavonoids, and steroids are found in leaves in relative abundance (Nisha, 2011). The secondary metabolites that contain medicinal properties are discussed throughout this paper, showing the importance of these extraction methods. Although the compounds have been identified, the exact bioactive compounds responsible for the medicinal properties are still unknown. Many of the compounds identified have unknown metabolic pathways and a variety of bioactive 
compounds may work in conjunction to elicit medicinal properties.

\subsection{Primary Metabolites}

Primary metabolites involved in metabolic pathways present in all plants. There are a few specific primary metabolites that have been extracted from T. procumbens: Lipids are essential in living organisms; they influence the communication between cells, the cellular makeup, and act as an energy source for the organism. $T$. procumbens contains common fats found in the Asteraceae family. This species also exhibits some lipids that give the plant unique properties and promising medicinal uses. These unique fats have been extracted and include: methyl 14-oxooctadecanoate, methyl 14 oxononacosanoate, 3-methylnonadecylbenzene, heptacosanyl cyclohexane carboxylate, 1(2,2-dimethyl-3-hydroxypropyl)-2-isobutyl phthalate, 12-hydroxytetracosan-15-one, 32-methyl-30-oxotetratriacont-31-en-1-ol and 30-methyl-28-oxodotriacont-29-en-1-oic acid dotriacontanol, $\beta$-amyrone, $\Delta^{12}$-dehydrolupen-3-one, $\beta$-amyrin, lupeol, fucosterol, 9-oxoheptadecane, 10-oxononadecane and sitosterol (Verma and Gupta, 1988). All these compounds play essential roles in plants and are common to many species.

\subsection{Secondary Metabolites}

Secondary metabolites are compounds produced by plants that are not essential for the normal growth and development of the plant, but play an important role in plant defenses, communication, stress responses and others. Secondary metabolites contain bioactive compounds that often have useful and important medicinal properties. Some of the most important bioactive compounds for medicinal uses are found in compounds such as glycosides, nitrogenous organic compounds, fat-soluble compounds, polyphenolic compounds, and minerals (Edeoga et al., 2005). T. procumbens secondary metabolites have been included into six major groups: flavonoids, carotenoids, alkaloids, saponins, tannins, and terpenes.

\subsubsection{Flavonoids}

Flavonoids are found in the leaves and other organs (Jhariya et al., 2015) and haves shown to be useful as anticoagulants, hair tonics, anti-fungal, against problems of bronchial catarrh, diarrhea, dysentery, and wound healing (Ali et al., 2001). The presence of procumbenetin and other flavonoids in Tridax seem to decrease the deposition of calcium and oxalate in the kidneys (Sailaja et al., 2012). This secondary metabolite seems to help regenerate damaged beta cells of the pancreas (Petchi et al., 2013). Evaluation of an aqueous extract of $T$. procumbens for its effect on diabetic rats showed hypoglycemic activity (assumed from flavonoids), protection against oxidative stress (probably due to high content of ascorbic acid) and lowering of VLDL cholesterol (probably due to the flavonoids) (Ikewuchi, 2012).

Luteolin and Quercetin were also isolated from Tridax, along with the flavonoid Procumbenetin (Jhariya et al., 2015). Lutein, glucoluteolin, and isoquercetin are found in the flowers of T. procumbens (Kumar et al., 2012). Luteolin has anti-inflammatory and anti-carcinogenic activity (Rao et al., 2012), probably due to its anti-oxidant activity and its free-radical scavenging ability (Seelinger et al., 2008). Luteolin has shown strong inhibition of tumor proliferation by suppressing angiogenesis (Kawaii et al., 1999). In vitro studies indicate that Luteolin has activity against different cancer cell lines including breast cancer (Tu et al., 2013), liver cancer (Pettit et al., 1996), hepatoma (Chang et al., 2005), colon cancer (Leung et al., 2006), human lung squamous carcinoma (Leung et al., 2005) and uterine cancer (Makino et al., 1998). In vivo studies have also shown anti-carcinogenic activity of Luteolin; for example, immunodeficient SCID mice and nude mice with prostate adenocarcinoma (Chiu and Lin, 2008; Markaverich et al., 1997; Fang et al., 2007) showed reduction in the size of the tumors when treated with Luteolin. Luteolin seems to slow the migration and invasion of cancer cells (Lin et al., 2008), inhibits cell replication and DNA repair, which promote apoptosis (Yamashita and Kawanishi, 2000) and inhibits multidrug-resistant proteins (Rao et al., 2012) among other effects. Quercetin is an antioxidant, protecting against lipid peroxidation, with effective antiulcer activity against ethanol-induced ulcerogenesis (Coskun et al., 2004); it also increases the level of beta-carotene and decreases the level of retinol (Bando et al., 2010). All these properties indicate the potential applications of this remarkable plant.

\subsubsection{Tannins}

Tannins are naturally occurring water-soluble polyphenols found in plants. Tannins have anti-microbial properties, as well as anti-carcinogenic and anti-mutagenic properties, potentially because of their antioxidant capabilities (Chung et al., 1998). Several researchers have described the presence of tannins in T. procumbens (Kumar et al., 2012, Edeoga et al., 2005). Acetone-water or Chloroform-water showed the presence of tannins in leaf extracts of T. procumbens (Table 3, Sawant and Godghate 2013). Tannins are present in the pedicle and buds of T. procumbens (Ikewuchi, 2012). 


\subsubsection{Carotenoids}

Carotenoids are fat-soluble pigments found in the leaves (Ikewuchi et al., 2009) that have three main functions in a plant: light-harvesting, protection from photooxidative damage, and pigmentation to attract insects. Carotenoids have been postulated to prevent damage to DNA by oxidative stress (Wagener et al., 2012). Many types of these secondary metabolites have been isolated from $T$. procumbens including beta-carotene, which can be converted to vitamin A (Ikewuchi et al., 2009), which is important for maintenance of epithelial tissues. Vitamin A deficiency can result in impairment of immunity and hematopoiesis, night blindness, and Xerophthalmia (Sommer, 1995). Carotenoids such as beta-carotene and lutein have shown activity in the reduction of UV-induced erythema (Heinrich et al., 2003). The photoprotective properties have also been linked with the antioxidant properties of carotenoids (Wagener et al., 2012).

\subsubsection{Alkaloids}

Alkaloids are defined as any class of nitrogenous organic compounds of plant origin that have pronounced physiological effects on humans. The presence of some alkaloids has also been reported in T. procumbens (Kumar et al., 2012). In a phytochemical screening analysis, using aqueous extraction of the leaves, thirty-nine alkaloids were present, mainly Akuamidine (73.91\%) and Voacangine (22.33\%) (Ikewuchi, 2012). Besides alkaloids, the extract contained sterols and tannins. Alkaloids of the pedicle and buds of $T$. procumbens showed antimicrobial activity against Proteus mirabilis and Candida albicans; alkaloids from buds showed activity against $E$. coli and Trichophyton mentagrophytes. The total amount of alkaloids in the pedicle was $32.25 \mathrm{mg} / \mathrm{gdw}$ in the pedicles and $92.66 \mathrm{mg} / \mathrm{gdw}$ in the buds (Jindal and Kumar, 2012). The presence of these alkaloids point once more to the great potential of this plant.

\subsubsection{Saponins}

Saponins are steroidal glycosides that contain pharmacological and medicinal properties (Atelle et al., 1999) and have been detected in $T$. procumbens (Edeoga et al., 2005), specifically a steroidal saponin and pB-Sitosterol-3-O- $\beta$-D-xylopyranoside in the flowers of the species (Saxena and Albert 2005). Another study determined that saponins from an ethanolic extract of $T$. procumbens could potentially contain antidiabetic properties by inhibiting the sodium glucose co-transporter-1 (S-GLUT-1) in the intestines of male Wistar albino rats (Petchi et al., 2013).

\section{Pharmacological Properties}

The great variety of secondary metabolites in Tridax, show the potential pharmacological properties of this species (Table 4), however, we have yet to see the use in allopathic medicine. These compounds have been used for their properties in anemia prevention, liver protection, immuno-enhancement, antioxidant, anticancer, antibacterial, antifungal, antiparasitic, antiplasmodial, and antiviral activities. This species could provide a bridge between traditional medicine and western medicine due to its pharmacological potential. More isolation and characterization of active components is needed. There is no research indicating whether there are changes in activity during the preparation and isolation of the pharmacological compounds.

Validation in table 4 is still required; for example, Ali et al. (2001) describes the isolation of flavonoids from aerial parts, but there is no correlation of the flavonoid procumbenetin to the antifungal activity. In other cases (Policegoudra et al., 2014), 26 compounds with putative antifungal activity were described but there is no reference to the phytochemicals responsible for the activity. In the work of Taddei and Romero (2002) there is no antimicrobial activity against Candida albicans contradicting the work done by Policegoudra and collaborators. It is possible that this is due to the different procedures used or to the type of bacterial strains used. Taddei and Romero used a three-extraction method for 7 days using dichloromethane $(1: 1 ; 3 \times 1000 \mathrm{ml})$ and further extraction of the aqueous layer with n-hexane followed by ethyl acetate, these authors also used paper disks for analysis and did not indicate the source of bacterial strains. Policegoudra fractionated the methanol extract with dichloromethane, used known bacterial strains and used the agar-well diffusion method. This indicates that additional work needs to be done to resolve the issue. 
Table 4. Pharmacological properties of Tridax procumbens

\begin{tabular}{|c|c|c|c|c|}
\hline $\begin{array}{l}\text { Pharmacological } \\
\text { Properties }\end{array}$ & Effect & Phytochemical & Extraction & Citation \\
\hline $\begin{array}{l}\text { Antimicrobial } \\
\text { Activity }\end{array}$ & $\begin{array}{l}\text { Bacillus Faecalis, B. subtilis, E. } \\
\text { coli, Pseudomonas aeruginosa, } \\
\text { Antibacterial and fungal infections }\end{array}$ & $\begin{array}{l}\text { Alpha and Beta } \\
\text { Pinenes, Alkaloids }\end{array}$ & $\begin{array}{l}\text { petroleum, ether and ethanolic } \\
\text { extracts from leaves, essences }\end{array}$ & $\begin{array}{l}\text { Jhample et al., } 2015 \\
\text { Manjamalai et al., 2012b; } \\
\text { Pai et al., } 2011\end{array}$ \\
\hline $\begin{array}{l}\text { Antifungal } \\
\text { Activity }\end{array}$ & $\begin{array}{l}\text { dermatophytes, Microsporum } \\
\text { fulvum, Microsporum gypseum, } \\
\text { Trichophyton mentagrophytes, } \\
\text { Trichophyton rubrum, Candida } \\
\text { albicans, and Trichosporon beigelii }\end{array}$ & $\begin{array}{l}\text { Flavonoids, } \\
\text { Monoterpenes, and } \\
\text { Alkaloids }\end{array}$ & Aerial parts- pedicle and buds & $\begin{array}{l}\text { Ali et al., 2001; Petchi et } \\
\text { al., 2013; Policegoudra et } \\
\text { al., } 2014\end{array}$ \\
\hline $\begin{array}{l}\text { Antibacterial } \\
\text { Activity }\end{array}$ & $\begin{array}{l}\text { Bacillus cereus, Mycobacterium } \\
\text { smegmatis, E. Coli, Staphylococcus } \\
\text { aureus, Klebsiella sp., Salmonella } \\
\text { group C, Salmonella paratyphi, } \\
\text { and Streptococcus pneumoniae }\end{array}$ & $\begin{array}{l}\text { Alpha and Beta } \\
\text { Pinenes }\end{array}$ & $\begin{array}{l}\text { N-hexane extracts, ethyl acetate } \\
\text { extract, essential oil extract, } \\
\text { chloroform extract }\end{array}$ & $\begin{array}{l}\text { Taddei and } \\
\text { Rosas-Romero, 2000, } \\
\text { Manjamalai et al., 2012b; } \\
\text { Dhanabalan et al., } 2008\end{array}$ \\
\hline $\begin{array}{l}\text { Antiparasitic } \\
\text { activity }\end{array}$ & $\begin{array}{l}\text { Malaria, dysentery, colic, and } \\
\text { vaginitis, } \\
\text { activity }\end{array}$ & $\begin{array}{l}\text { (3,S)-16,17-Didehydr } \\
\text { ofalcarinol an } \\
\text { oxylipin. }\end{array}$ & $\begin{array}{l}\text { bioassay guided fractionation } \\
\text { with a methanol extract }\end{array}$ & $\begin{array}{l}\text { Martín-Quintal et al., } \\
2009\end{array}$ \\
\hline $\begin{array}{l}\text { Antioxidant } \\
\text { Activity }\end{array}$ & $\begin{array}{l}\text { Antioxidant, anti-inflammatory, } \\
\text { anti-cancer. }\end{array}$ & $\begin{array}{l}\text { High phenol content, } \\
\text { Flavonoids (in water } \\
\text { phase), Carotenoids } \\
\text { (in lipid phase), } \\
\text { Alkaloids }\end{array}$ & $\begin{array}{l}\text { Ethyl acetate and } \mathrm{n} \text {-Butanol } \\
\text { fractions obtained r from } \\
\text { methanolic extracts, essential } \\
\text { oils }\end{array}$ & $\begin{array}{l}\text { Saxena et al., 2013; } \\
\text { Habila et al., 2010; Han } \\
\text { et al., 2012; Manjamalai } \\
\text { and Berlin Grace, 2004, } \\
\text { Jachak et al., 2017. }\end{array}$ \\
\hline $\begin{array}{l}\text { Anticancer } \\
\text { Activity }\end{array}$ & $\begin{array}{l}\text { Potent cytotoxic activity against } \\
\text { malignant tumor cells. }\end{array}$ & $\begin{array}{l}\text { 5(alpha)- cholestane, } \\
\text { monoterpenes (alpha } \\
\text { and beta pinenes) }\end{array}$ & $\begin{array}{l}\text { Crude flower aqueous and } \\
\text { acetone extracts, essential oil } \\
\text { extract }\end{array}$ & $\begin{array}{l}\text { Vishnu et al., 2011; } \\
\text { Manjamalai et al., 2012a; } \\
\text { Policegoudra et al., 2014 }\end{array}$ \\
\hline $\begin{array}{l}\text { Hepatoprotective } \\
\text { Activity }\end{array}$ & $\begin{array}{l}\text { Reduction of oxidative stress, } \\
\text { lowered levels of serum Aspartate } \\
\text { aminotransferase, serum Alanine } \\
\text { aminotransferase, serum Alkaline } \\
\text { phosphatase, and serum bilirubin in } \\
\text { rats }\end{array}$ & $\begin{array}{l}\text { Alkaloids, } \\
\text { Flavonoids }\end{array}$ & $\begin{array}{l}\text { Flowers, leaves, and aerial parts. } \\
\text { chloroform insoluble fraction of } \\
\text { an ethanol extract, petroleum } \\
\text { ether, methanol, and chloroform } \\
\text { water extracts, } \\
\text { Lipopolysaccharide chloroform- } \\
\text { insoluble fraction, aqueous } \\
\text { extracts }\end{array}$ & $\begin{array}{l}\text { Ravikumar et al., 2005a; } \\
\text { Ravikumar et al., 2005b; } \\
\text { Patel et al., 2014; } \\
\text { Nwange, 2008. }\end{array}$ \\
\hline $\begin{array}{l}\text { Immunoenhance } \\
\text { ment Activity }\end{array}$ & $\begin{array}{l}\text { Activation of the immune system } \\
\text { with an increase of percent in } \\
\text { neutrophils in rats }\end{array}$ & $\begin{array}{l}\text { Sequesterpene } \\
\text { triterpenoids }\end{array}$ & No Data Found & Tiwari et al., 2004 \\
\hline $\begin{array}{l}\text { Antidiabetic } \\
\text { Properties }\end{array}$ & $\begin{array}{l}\text { antidiabetic activity that is } \\
\text { comparable to the drug } \\
\text { Glibenclamide in rats. }\end{array}$ & Saponins & $\begin{array}{l}\text { Ethanolic extract of whole } \\
\text { plants, pet ether, methanol, and } \\
\text { chloroform extracts }\end{array}$ & $\begin{array}{l}\text { Sonawane et al., 2014; } \\
\text { Petchi et al., } 2013\end{array}$ \\
\hline $\begin{array}{l}\text { Antihypertensive } \\
\text { Activity }\end{array}$ & $\begin{array}{l}\text { Antihypertensive activity } \\
\text { comparable to the drug captopril in } \\
\text { rats }\end{array}$ & $\begin{array}{l}\text { Flavonoids and } \\
\text { potentially alkaloids }\end{array}$ & $\begin{array}{l}\text { ethyl acetate and } \\
\text { dichloromethane fractions from } \\
\text { the aerial parts of the plant }\end{array}$ & Adjagba et al., 2015 \\
\hline
\end{tabular}

\subsection{Antimicrobial Activity}

Antimicrobial screenings have been done, but additional studies are needed to corroborate some of the results. Various species of bacteria and fungi have shown sensitivity to the antimicrobial properties of T. procumbens. More recently, callus of stem and leaf has shown to be useful for the synthesis of silver nanoparticles that showed some antimicrobial activity against E. coli, V. cholerae, A. niger, and A flavus (Bhati-Kushwaha and Malik, 2014). However, this activity was lower than the activity shown by silver nitrate so these results are not conclusive.

Petroleum, ether and ethanolic extracts of leaves of T. procumbens showed antibacterial activity against Bacillus faecalis. This activity was reported to be probably due to the presence of alkaloids. The chloroform extracts showed antibacterial activity against B. faecalis, B. subtilis, E. coli, and Pseudomonas aeruginosa (Christudas et al., 2012) but the experiments need better controls and descriptions of the procedures. Essences from $T$. procumbens show the presence of alpha and beta pinenes, used in small quantities can help in treating bacterial and fungal infections (Manjamalai et al., 2012b). There are some contradictory results about the antimicrobial activity of this species (e.g. Policegoudra et al., 2014; Taddei and Romero, 2002). Some studies did not include significant biological activity compared to the antibiotic control (e.g. Jhample et al., 2015) but there is evidence for the potential of this species as anti-microbial so more studies need to be done in this area 


\subsubsection{Antifungal Activity}

Antifungal activity of T. procumbens has been investigated. Different extraction methods have been used to find the optimum zone of inhibition from different fungal strains including Microsporum fulvum, Microsporum gypseum, Trichophyton mentagrophytes, Trichophyton rubrum, Candida albicans, and Trichosporon beigelii. Extracts of the aerial parts of this plant have shown activity against dermatophytes with zones of inhibition ranging from 17 to $25 \mathrm{~mm}$ with dichloromethane (DCM) fraction resulting in the best response (Policegoudra et al., 2014). However, the authors do not describe which ones are the bioactive compounds responsible for the antifungal properties. The authors suggest that these compounds could be fatty acid derivatives and constituents but no evidence is given about this statement.

\subsubsection{Antibacterial Activity}

Tridax procumbens has shown to have antibacterial activity. It is one of the most common plants for treating bacterial infections in rural parts of the world (Taddei and Rosas-Romero, 2000). Tridax extracts have shown to be effective against a variety of bacteria. N-hexane extracts have activity against Mycobacterium smegmatis, E. coli, Klebsiella sp., Salmonella group C, and Salmonella paratyphi. The ethyl acetate extract was effective against Gram-positive bacteria such as Bacillus cereus, Mycobacterium smegmatis, Staphylococcus aureus, and Gram-negative bacteria such as Klebsiella sp. (Taddei and Rosas-Romero, 2000). The essential oil extract of $T$. procumbens shows significant activity against Gram-positive bacteria: Staphylococcus aureus and Streptococcus pneumoniae (Manjamalai et al., 2012b). There are some differences in how the studies were conducted so even though there seem to be strong support for the antibacterial activity of this species, more comprehensive research needs to be done.

\subsubsection{Antiparasitic Activity}

Treatment of some diseases caused by protozoal infections like malaria (Appiah-Opong et al., 2011; Komlaga et al., 2015), dysentery, colic, and vaginitis have been assessed with $T$. procumbens through a bioassay guided fractionation with a methanol extract to isolate an active compound, (3,S)-16,17-Didehydrofalcarinol (an oxylipin). Tridax seemed to have anti-leishmanial activity when using crude extracts from the whole plant (Martín-Quintal et al., 2009). A study done in Ghana tested the antiplasmodial effect of aqueous, chloroform, ethyl acetate, and ethanolic extracts from the flowers, leaves, and stem of T. procumbens. There is evidence that the aqueous and ethanolic extracts from the species have anti-plasmodial properties; a study using the tetrazolium-based colorimetric assay showed that $T$. procumbens helped protect red blood cells from $P$. falciparum damage (Appiah-Opong et al., 2011). Tridax shows a great potential against a disease that kills millions of people around the world.

\subsection{Antioxidant Activity}

Free radicals are molecules that have an unpaired electron in an atomic orbital making them highly reactive. Some of these free radicals include reactive hydroxyl radicals $(\mathrm{OH})$, superoxide anion radicals, hydrogen peroxides, reactive oxygen species (ROS), and peroxyl. The instability of these radicals can damage many biologically important molecules like DNA and macromolecules, thus leading to cell damage and homeostatic disturbance. An antioxidant or a free radical scavenger is used to reduce this activity by preventing the oxidation within a biological system. Agrawal et al. (2009) analyzed the antioxidant activity of T. procumbens and found significant activity (comparable to the activity of Ascorbic acid) in the ethyl acetate and n-butanol fractions obtained from methanolic extracts, when using the 1,1-diphenyl-2-picrylhydrazyl (DPPH) method. Saxena et al., (2013) also reported a high antioxidant activity of Tridax when using n-butanol and ethyl acetate fractions from methanolic extracts. Habila et al., (2010) found a 96.7\% antioxidant activity at a concentration of $250 \mu \mathrm{g} / \mathrm{mL}$. The authors report a high reductive potential in Tridax $(0.89 \mathrm{~nm})$ compared to the standard $(0.99 \mathrm{~nm})$ and postulate that this strong antioxidant activity could be due to the high phenol content of the plant, making this plant a good natural source of antioxidants with potential medicinal value. T. procumbens is also said to reduce lipid peroxidation as well as induce enzymatic and non-enzymatic antioxidants. The hepatoprotective nature of the plant may be due to flavonoids, which have been known hold free radical scavenging properties (Ravikumar et al., 2005b). The strong anti-oxidant activity of T. procumbens is due to the high content of phenols, flavonoids, anthraquinone, carotenoids and vitamins A and C (Nisha, 2011). All the studies report strong support for the antioxidant properties of Tridax.

The essential oils of $T$. procumbens have shown antioxidant activity by reducing the levels of oxidative stress when using the DPPH assay. These essential oils seem to have higher antioxidant activity than ascorbic acid and increasing the concentration of the essential oil seemed to increase the antioxidant power. It is postulated that this characteristic of $T$. procumbens makes it a great candidate for the treatment of inflammation and cancer with 
less toxic effects (Manjamalai and Grace, 2004) but these claims are not properly researched and documented. For example, T. procumbens has shown to reduce inflammation when applied as a leaf poultice and it has shown to be effective in the treatment of neuropathic and inflammatory pain in rodent models (Sawant et al., 2014). Extract from the leaves of the plant decreased the severity of carrageenan-induced rat paw inflammation. $T$. procumbens extract at dosages of $100 \mathrm{mg} / \mathrm{kg}, 200 \mathrm{mg} / \mathrm{kg}$, and $400 \mathrm{mg} / \mathrm{kg}$ did a better job of reducing edema than aspirin at the same dosages. The plant extract did not produce ulceration and proved to be safer than aspirin and phenylbutazone (Diwan et al., 1989). Another study done more recently showed similar results. T. procumbens aqueous extract from the leaves showed to reduce carrageenan-induced paw inflammation. In this study the plant extract was compared to Ibuprofen instead of aspirin (Awasthi et al., 2009), but both studies show the positive effect of Tridax in reducing inflammation without the potential issues that could arise from the use of Aspirin or Ibuprofen.

\subsection{Anticancer Activity}

Cancer is a multifactorial disease. Only until recently has the anticancer activity of $T$. procumbens been researched. Crude flower aqueous and acetone extracts were tested on prostate epithelial cancerous cells (PC3). Very weak anticancer activity was observed with the aqueous extract. The acetone extract showed an $82.28 \%$ activity against cancer cells within 24 hours of treatment (Vishnu et al., 2011). The viability was analyzed using the MTT assay. The authors don't explain the toxicity analysis so the results are inconclusive since the only extract that had effect was the acetone extract and the controls are not clearly indicated in the publication. This study also does not compare the results to standard therapeutic drugs and there is no report of the selectivity index.

Significant inhibition of tumor nodule formation in the lungs was observed when using $T$. procumbens, probably due to the inhibition of formation of new blood vessels in response to monoterpenes (alpha and beta pinenes). There was also an increase of expression with P53 and caspase; indicating that the oils of this plants could induce apoptosis. Different studies have indicated that T. procumbens shows promise in the treatment of cancer, but more research needs to be done in order to understand the molecular mechanisms involved in this activity (Manjamalai et al., 2012a). In addition, none of the work done on anticancer activity followed the proper protocols for research in this area so the research is inconclusive.

\subsection{Hepatoprotective Activity}

Many models have been used to evaluate the effect that $T$. procumbens has on reducing oxidative stress in the liver, which leads to liver injury, and the hepatoprotective activity of different extracts. The chloroform insoluble fraction of an ethanol extract is effective for alleviating liver stress caused by pharmacological agents that create the same pathologies as viral hepatitis, drug intoxication, and lipid peroxidation from a reactive oxidative species (Hemalatha, 2008). A different study showed that the chloroform insoluble extract of the ethanol extract reduced hepatotoxic activity by reducing the amounts of different enzymes in rats that had been treated with $\mathrm{CCl}_{4}(\mathrm{Saraf}$ and Dixit, 1991). Research done on male albino rats evaluated the use of $T$. procumbens as a treatment for liver damage caused by Paracetamol (acetaminophen). It was determined that when the ethanolic extract from $T$. procumbens was administered orally at varying dosages, it lowered the levels of serum Aspartate aminotransferase, serum Alanine aminotransferase, serum Alkaline phosphatase, and serum bilirubin, resulting in hepatoprotection (Wagh and Shinde, 2010). Petroleum ether, methanol, and chloroform water extracts from flowers showed protection against hepatotoxicity in Male Wister Albino Rats, with the methanolic extract showing the best effect (Patel et al., 2014). Aqueous extracts of leaves have shown hepatoprotective activity in rats because of the antioxidant activity of these extracts, due to the active free radical scavenging (Nwanjo, 2008). An ethanolic extract from leaves of $T$. procumbens that was fractionated with chloroform showed good hepatoprotective activity in rats that had induced hepatitis by d-Galactosamine Lipopolysaccharide. The study suggests that pretreatment with the plant extract may have caused parenchymal cell regeneration in the liver. The rats that were pretreated also restored their lipid levels to normal after being treated with d-Galactosamine Lipopolysaccharide. Rats that were treated with only the T. procumbens extract showed to no adverse reactions, suggesting that the plant has little to no toxicity in rats. The hepatoprotective activity appeared to be from the presence of flavonoids (Ravikumar et al., 2005a). The hepatoprotective properties of Tridax seem to be promising and warrants future research.

\subsection{Immuno-enhancement Activity}

Various bioactive compounds have aided in normalization of immune response to assuage certain diseases. An adaptogen of Tridax procumbens has shown to enhance the body's nonspecific resistance against pathogens. Various tests in mice evaluated the effect of Tridax in stimulating the immune system, including the use of Swiss 
Albino Mice treated with immunomodulators present in T. procumbens and shown to activate the immune system. This work compared the Delayed-type hypersensitivity (DTH) in the animals fed with the extracts versus the controls to evaluate cell-mediated immunity. In addition, the neutrophil adhesion was investigated showing a dose-dependent increase in the DTH response and an increase in the percentage of neutrophils. The authors suggest that there was enough evidence for the initiation of clinical trials in immunocompromised patients (Agrawal et al., 2011). However, we think that more in-depth studies should be done before clinical trials can be initiated. Even though research has shown that $T$. procumbens does possess immunostimulators, it is unclear what constituents are immunostimulators, and what constituents are immunosuppressants; different extraction and fractionation methods need to be done and then each solution tested to determine the constituents (Tiwari et al., 2004) and their activity.

\subsection{Antidiabetic Properties}

Diabetes has become a worldwide epidemic; interestingly, T. procumbens has shown antidiabetic properties. Streptozotocin-induced Male Wistar albino diabetic rats were given ethanolic extracts from the whole plant of $T$. procumbens. The study showed that the extract had antidiabetic activity that is comparable to the drug Glibenclamide used to treat diabetes mellitus type 2. The drug works by increasing the amount of insulin produced by the pancreas (Petchi et al., 2013). This study included proper controls and two different concentrations of whole plant extract of Tridax $(250 \mathrm{mg} / \mathrm{Kg}$ and $500 \mathrm{mg} / \mathrm{Kg})$. ANOVA and Dennett's post hoc test showed significant antidiabetic activity compared to the controls. The extracts also showed a positive effect against hyperlipidaemia associated with diabetes mellitus.

Another study showed that Alloxan-induced diabetic male albino rats responded better to methanolic extracts of T. procumbens than to the common drug Glibenclamide. The plant extracts were given to rats in 250 or 500 $\mathrm{mg} / \mathrm{kg}$ doses, while the Glibenclamide was given at a $10 \mathrm{mg} / \mathrm{kg}$ dose. The results showed that either dosage of the plant extract lowered the blood glucose levels in the rats by $10.96 \%-13.74 \%$ better than the conventional drug after 6 hours of treatment. The plants extracts also showed an improvement in the fasting blood glucose levels of the Alloxan-induced diabetic rats. There was also no evidence of adverse side effects of Tridax's methanolic extracts on the diabetically-induced animals. The effects of the plants on the rat's body weight was also studied (Pareek et al., 2009).

In a study done by Bhagwat et al. (2008), oral administration of aqueous and alcoholic extracts from the leaves of $T$. procumbens significantly decreased blood sugar levels in Alloxan-induced Wistar diabetic rats. The rats were given the extract for seven consecutive days at a dosage of $200 \mathrm{mg} / \mathrm{kg}$. The authors do not specify the mechanism of action of the Tridax extracts but this study corroborates other studies on the antidiabetic properties of this species.

T. procumbens slowed the rate of both alpha amylase and alpha glucosidase enzymes with ether, methanol, and chloroform extracts showing a significant reduction, enough to resemble common drugs used to slow the enzymes in diabetes treatment (Sonawane et al., 2014). Alpha-amylase and the Alpha-glucosidase enzymes are responsible for the breakdown of carbohydrate molecules, by slowing their breakdown rate, allowing the body to digest these carbohydrates in lower doses and therefore slowing the need for insulin, which is the main chemical affected in diabetes mellitus (Sonawane et al., 2014). All these studies demonstrate the great pharmacological potential of Tridax against diabetes and the importance of further research and clinical studies that could evaluate the effect in humans.

\subsection{Antihypertensive Activity}

For adults over 20, hypertension, or high blood pressure, is any measurement where the systolic number is above $140 \mathrm{mmHg}$, and the diastolic reading is above $90 \mathrm{mmHg}$. The CDC also characterized people who were taking medications to lower their pressure as individuals with hypertension. From 2009-2012, 30\% of Americans, over the age of 20, had high blood pressure (National Center for Health Statistics). In Benin and other countries, Tridax procumbens has been traditionally used for the treatment of hypertension (Salami et al., 2017; Adjagba et al., 2015). Because of its traditional history, a study was done looking into its antihypertensive activity. The aerial parts of the plant were used to make cyclohexane, micellar, dichloromethane, and ethyl acetate fractions from a crude aqueous extract. Rats were treated with $20 \mathrm{mg} / \mathrm{kg}$ of $\mathrm{N}$ (G)-Nitro-L-Arginine-Methyl Ester (L-NAME) for seven days to induce hypertension; they were then treated with the different extracts for seven more days. The ethyl acetate and dichloromethane fractions were most effective in lowering the mean arterial pressure of the rats. The data was comparable to the effect that the common drug captopril had on the rats. Both the ethyl acetate and dichloromethane fractions contained alkaloids and flavonoids, potentially showing that those phytochemicals are responsible for the lowering of the blood pressure. There are several ideas for what the 
mechanism of action is; one thought is that flavonoids can be responsible for vasorelaxation, which helps lower blood pressure. It is also said that flavonoids may have a diuretic effect that may also explain part of the plants antihypertensive activity (Adjagba et al., 2015).

\section{Discussion}

This review shows the importance and need to continuously research plants known to be used in traditional medicinal that could lead to the discovery and creation of new conventional medicines. Tridax procumbens has a long history of traditional use but isolation and evaluation of each phytochemical has not been properly related to its pharmacological properties and could show difficulty in reproducibility after isolation and evaluation. Different extracts have been used for isolation of metabolites and for treating different ailments. Based on the reviewed material many extraction studies analyzed did not do confirmatory work and some studies contradicted others. It appears that many of the extraction methods show some positive effect in a variety of disorders. Data indicates a positive effect of Tridax as an anti-diabetic when compared to conventional medicine. At the time of the writing of this review, there was no research indicating the concentration of specific phytochemicals in different plant organs, thus, determining dosage based on traditional uses is not possible. Future research needs to focus on the connection between specific phytochemical and their effects on various ailments. Others areas that have yet to be studied in depth include, but are not limited to yield of extraction, concentration and physiological activity of these phytochemicals. Discoveries in these areas will provide important information that could be used by the health community for preventative medicine and/or the discovery of new drugs. $T$. procumbens still has many important properties that remain to be discovered.

\section{References}

Aboh, A. B., Olaafa, M., Dossou-Gbété, G. S. O., Dossa, A. D., \& Djagound, N. (2002). Ingestion volontaire et digestibilité apparente d'une ration à base de la farine de grains de Mucuna pruriens var. utilis complétée de fourrages chez les lapins. Tropiculture, 20(4), 165-169.

Adjagba, M., Awede, B., Nondichao, K., Lagnika, L., Osseni, R., Darboux, R., Laleye, A. (2015). Antihypertensive activity of different fractions of Tridax procumbens crude aqueous extract in wistar rats. Journal of Physiology and Pharmacology Advances, 5(9), 713-719. https://doi.org/10.5455/jppa.20150917122209

Agban, A., Gbogbo, K. A., Amana, E.K., Tegueni, K., Batawila, K., Koumaglo, K., \& Akpagana, K. (2013). Evaluation des activités antimicrobiennes de Tridax procumbens (Asteraceae), Jatropha multifidi (Euphorbiaceae) et de Chromolaena odorata (Asteraceae). European Scientific Journal, 9(36), 278-290.

Agrawal, S. S., Talele, G. S., \& Surana, S. J. (2009). Antioxidant activity of fractions from Tridax procumbens. Journal of Pharmacy Research, 2(1), 71-73.

Agrawal, S., \& Talele, G. (2011). Bioactivity guided isolation and characterization of the phytoconstituents from the Tridax procumbens. Revista Brasileira de Farmacognosia, 21(1), 58-62. https://doi.org/10.1590/S0102-695X2011005000011

Agyare, C., Boakye, Y. D., Bekoe, E. O., Hensel, A., Dapaah, S. O., \& Appiah, T. (2016). Review: African medicinal plants with wound healing properties. Journal of Ethnopharmacology, 177, 85-100. https://doi.org/10.1016/j.jep.2015.11.008

Ali, M., Ravinder, E., \& Ramachandram, R. (2001). Phytochemical communication: A new flavonoid from the aerial parts of Tridax procumbens. Fitoterapia, 72(3), 313-315. https://doi.org/10.1016/S0367-326X(00)00296-3

Ankita, J., \& Jain, A. (2012). Tridax procumbens (L.): A weed with immense medicinal importance: A review. International Journal of Pharma and Bio Sciences, 3(1), 544-552.

Appiah-Opong, R., Nyarko, A. K., Dodoo, D., Gyang, F. N., Koram, K. A., \& Ayisi, N. K. (2011). Antiplasmodial activity of extracts of Tridax procumbens and Phyllanthus amarus in in vitro Plasmodium falciparum culture system. Ghana Med J., 45(4), 143-150.

Atelle, A., Wu, J. A., \& Yuan, C. (1999). Ginseng pharmacology. Multiple constituents and multiple actions. Biochemical Pharmacology, 58(11), 1685-1693. https://doi.org/10.1016/S0006-2952(99)00212-9

Awasthi, S., Irshad, M., Das, M. K., Ganti, S. S., \& Moshahid, A. R. (2009). Anti-inflammatory activity of Calotropis gigantea and Tridax procumbens on carageenin-induced paw edema in rats. Ethnobotanical Leaflets, 13(5), 568-577. 
Ayyappa, D. M. P., Dhanabalan, R., Doss, A., \& Palaniswamy, M. (2009). Phytochemical screening and antibacterial activity of aqueous and methanolic leaf extracts of two medicinal plants against bovine mastitis bacterial pathogens. Ethnobotanical leaflets, 13(1), 131-139.

Bando, N., Muraki, N., Murota, K., Terao, J., \& Yamanishi, R. (2010). Ingested quercetin but not rutin increases accumulation of hepatic beta-carotene in BALB/c mice. Molecular Nutrition and Food Research, 54(2), 261-267. https://doi.org/10.1002/mnfr.200900329

Berger, I., Barrientos, A. C., Cáceres, A., Hernández, M., Rastrelli, L., Passreiter, C. M., \& Kubelka, W. (1998). Plants used in Guatemala for the treatment of protozoal infections: II. Activity of extracts and fractions of five Guatemalan plants against Trypanosoma cruzi. J. Ethnopharmacol., 62(2), 107-115. https://doi.org/10.1016/S0378-8741(98)00011-7

Bhagwat, D. A., Killedar, S. G., \& Adnaik, R. S. (2008). Anti-diabetic activity of leaf extract of Tridax procumbens. International Journal of Green Pharmacy, 2(2), 126-128.https://doi.org/10.4103/0973-8258.41188

Bhati-Kushwaha, H., \& Malik, C. P. (2014). Assessment of antibacterial and antifungal activities of silver nanoparticles obtained from the callus extracts (stem and leaf) of Tridax procumbens L. Indian Journal of Biotechnology, 13(1), 114-120.

Byavu, N., Hnrard, C., Dubois, M., \& Malaisse, F. (2000). Phytothérapie traditionelle des bovins dans les élevages de la plaine de la Ruzizi. Biotechnol. Agron. Soc. Environ., 4(3), 135-156.

Caceres, A., López, B., González, S., Berger, I.,Tada, I., Maki, J. (1998). Plants used in Guatemala for the treatment of protozoal infections. I. Screening of activity to bacteria, fungi and American trypanosomes of 13 native plants. J. Ethnopharmacol., 62(3), 195-202. doi:10.1016/S0378-8741(98)00140-8

Chang, J., Hsu, Y., Kuo, P., Kuo, Y., Chiang, L., \& Lin, C. (2005). Increase of Bax/ Bcl-XL ratio and arrest of cell cycle by luteolin in immortalized human hepatoma cell line. Life Sci., 76(16), 1883-1893.

https://doi.org/10.1016/j.lfs.2004.11.003

Chauhan, B. S., \& Johnson, D. E. (2008). Germination ecology of two troublesome Asteraceae species of rainfed rice: Siam weed (Chromolaena odorate) and Coat buttons (Tridax procumbens). Weed Science, 56(4), 567-573. https://doi.org/10.1614/WS-07.200.1

Chiu, F. L., \& Lin, J. K. (2008). Downregulation of androgen receptor expression by luteolin causes inhibition of cell proliferation and induction of apoptosis in human prostate cancer cells and xenografts. Prostate, 68(1), 61-71. https://doi.org/10.1002/pros.20690

Christudas, S., Kulathivel, T. M., \& Agastian, P. (2012). Phytochemical and antibacterial studies of leaves of Tridax procumbens L. Asian Pacific Journal of Tropical Biomedicine, 2(1), 159-161. https://doi.org/10.1016/S2221-1691(12)60149-X

Chung, K., Wong, T., Wei, C., Huang, Y., Lin. (1998). Tannins and human health: a review. Critical Reviews in Food Science and Nutrition, 38(6), 421-464. https://doi.org/10.1080/10408699891274273

Coskun, O., Kanter, M., Armutcu, F., Cetin, K., Kaybolmaz, B., \& Yazgan, O. (2004). Protective effects of quercetin, a flavonoid antioxidant, in absolute ethanol-induced acute gastric ulcer. Eur. J. Gen Med., 1(3), 37-42. https://doi.org/10.29333/ejgm/82201

Dhanabalan, R., Doss, A., Jagadeeswar, M., Balanchandar, S., Kezia, E., Parivuguna, V., Reena Josephine, C. M., Vaidheki, R., \& Kalamani, K. (2008). In vitro phytochemical screening and antibacterial activity of aqueous and methanolic leaf extracts of Tridax procumbens against bovine mastitis isolated Staphylococcus aureus. Ethnobotanical Leaflets, 12, 1090-1095.

Diwan, P., Karwande, I., Margaret, I., \& Sattur, P. B. (1989). Pharmacology and biochemical evaluation of Tridax procumbens on inflammation. Indian Journal of Pharmacology, 21(2), 1-7.

Ebiloma, G. U., Igoli, J. O., Katsoulis, E., Donachie, A. M., Eze, A., Gray, A. I., \& Koning, H. P. (2017). Bioassay-guided isolation of active principles from Nigerian medicinal plants identifies new trypanocides with low toxicity and no cross-resistance to diamidines and arsenicals. Journal of Ethnopharmacology, 202, 256-264.https://doi.org/10.1016/j.jep.2017.03.028

Edeoga, H., Okwu, D., \& Mbaebie, B. (2005). Phytochemical constituents of some Nigerian medicinal plants. African Journal of Biotechnology, 4(7), 685-688. https://doi.org/10.5897/AJB2005.000-3127

Fabricant, D., \& Farnsworth, N. (2001). The value of plants used in traditional medicine for drug discovery. 
Environmental Health Perspectives, 109(1), 69-75. https://doi.org/10.1289/ehp.01109s169

Fang, J., Zhou, Q., Shi, X. L., \& Jiang, B. H. (2007). Luteolin inhibits insulin-like growth factor 1 receptor signaling in prostate cancer cells. Carcinogenesis, 28(3), 713-723. https://doi.org/10.1093/carcin/bgl189

Foret, R., de la, "Herbal Energetics.” Herbs with Rosalee. (2012). Retrieved April 16, 2015. <http://www.herbalremediesadvice.org/herbal-energetics.html>

Gamboa-Leon, R., Vera-Ku, M., Peraza-Sanchez, S. R., Ku-chulim, C., Horta-Baas, A., \& Rosado-Vallado, M. (2014). Antileishmanial activity of a mixture of Tridax procumbens and Allium sativum in mice. Parasite, 21(15). https://doi.org/10.1051/parasite/2014016

Habila, J. D., Bello, I. A., Dzikwi, A. A., Musa, H., \& Abubakar, N. (2010). Total phenolics and antioxidant activity of Tridax procumbens Linn. African Journal of Pharmacy and Pharmacology, 4(3), 123-126.

Han, R. M., Zhang, J. P., \& Skibsted, L. H. (2012). Reaction Dynamics of Flavonoids and Carotenoids as Antioxidants. Molecules, 17(2), 2140-2160. https://doi.org/10.3390/molecules17022140

Harborne, J. B. (1994). Indian Medicinal Plants. A Compendium of 500 Species. Vol.1; Edited by P. K. Warrier, V. P. K. Nambiar and C. Ramankutty. Journal of Pharmacy and Pharmacology, 46(11), 935. https://doi.org/10.1111/j.2042-7158.1994.tb05722.x

Heinrich, U., Gartner, C., Wiebusch, M., Eichler, O., Sies, H., Tronnier, H., \& Stahl, W. (2003). Supplementation with Beta-Carotene or a Similar Amount of Mixed Carotenoids Protects Humans from UV-Induced Erythema. The American Society for Nutritional Sciences, 133(1), 98-101.

Hemalatha, R. (2008). Anti-hepatotoxic and anti-oxidant defense potential of Tridax procumbens. International Journal of Green Pharmacy, 2(3), 164-169.https://doi.org/10.4103/0973-8258.42736

Hilliard, O. M. (1977). Compositae in Natal. Pietermaritburg. South Africa: University of Natal Press.

Hitesh, J. (2006). Formulation and evaluation of analgesic activity of Tridax procumbens Gel. Indian J. of Nat. Prod., 23(1), 31-33.

Holm, L., Doll, J., Holm, E., Pancho, J., \& Herberger, J. (1997). World Weeds: Natural Histories and Distribution. John Wiley \& Sons, Inc. New York.

Ikewuchi, J. C. (2012). Alteration of Plasma Biochemical, Haematological and Ocular Oxidative Indices of Alloxan Induced Diabetic Rats by Aqueous Extract of Tridax procumbens Linn (Asteraceae). EXCLI Journal, 11, 291-308.

Ikewuchi, J. C., Ikewuchi, C. C., \& Ngozi, M. I. (2009). Chemical profile of Tridax procumbens Linn. Pakistan Journal of Nutrition, 8(5), 548-550. https://doi.org/10.3923/pjn.2009.548.550

ITIS. ND. www.itis.gov

Jachak, S. M., Gautam, R., Selvam, C., Madhan, H., ASrivastava, A., \& Kah, T. (2017). Anti-inflammatory, cyclooxygenase inhibitory and antioxidant activities of standardized extracts of Tridax procumbens $\mathrm{L}$. Fitoterapia, 82, 173-177. https://doi.org/10.1016/j.fitote.2010.08.016

Jhample, S. B., Gajdhane, S. B., Kasabe, P. J., Bhagwat, P. K., \& Dandge, P. B. (2015). Phytochemical screening and in vitro antimicrobial activity of Tridax procumbens L. Research Journal of Life Sciences, Bioinformatics, Pharmaceutical and Chemical Sciences, June, 44-56.

Jhariya, S., Rai, G., Yadav, A. K., Jain, A. P., \& Lodhi, S. (2015). Protective effects of Tridax procumbens Linn. Leaves on experimentally induced gastric ulcers in rats. Journal of Herbs, Spices \& Medicinal Plants, 21(3), 308-320. https://doi.org/10.1080/10496475.2014.973083

Jesmin, S., Sarker, M. A. Q., \& Alam, M. F. (2013). Multiple shoot proliferation in Tridax procumbens L. through in vitro method. International Journal of Biosciences, 3(7), 177-187. https://doi.org/10.12692/ijb/3.7.177-187

Jindal, A., \& Kumar, P. (2012). Antimicrobial activity of alkaloids of Tridax procumbens L. against human pathogens. International Journal of Pharmaceutical Sciences and Research, 3(9), 3481-3485.

Jhariya, S., Rai, G., Yakav, A. K., Jain, A. P., \& Lodki, S. (2015). Protective Effects of Tridax procumbens Linn. Leaves of Experimentally Induced Gastric Ulcers in Rats. Journal of Herbs, Spices, and Medicinal Plants, 21(3), 308-320. https://doi.org/10.1080/10496475.2014.973083

Kawaii, S., Tomono, Y., Katase, E., Ogawa, K., \& Yano, M. (1999). Antiproliferative activity of flavonoids on 
several cancer cell lines. Biosci. Biotechnol. Biochem, 63(5), 896-899.https://doi.org/10.1271/bbb.63.896

Kamble, S. I., \& Dahake, P. R. (2015). Preliminary phytochemical investigation and study on antimicrobial activity of Tridax Procumbens Linn. International Refereed Multidisciplinary Journal of Contemporary Research, 2(3), 388-394.

Kethamakka, S. R. P., \& Deogade, M. S. (2014). Javanti veda (Tridax procumbens) unnoticed medicinal plant by Ayurveda. Journal of Indian System of Medicine, 2(1), 6-20.

Komlaga, G., Aguare, C., Dickson, R. A., Mensah, M. L. K., Anan, K., Loiseau, P. M., \& Champy, P. (2015). Medicinal plants and finished marketed herbal products used in the treatment of malaria in the Ashanti region, Ghana. Journal of Ethnopharmacology, 172, 333-346.https://doi.org/10.1016/j.jep.2015.06.041

Koram, K. A., Ahorlu, C. S. K., Wilson, M. D., Yeboah-Manu, D., \& Bosompem, K. M., (Eds). (2014). Towards Effective Disease Control in Ghana: Research and Policy Implications. Volume 1: Malaria. University of Ghana Readers. Subsaharan Publishers.

Kumar, L., Prasad, A., Iyer, S., \& Vaidya, S. (2012). Pharmacognostical, phytochemical and pharmacological review on Tridax procumbens. International Journal of Pharmaceutical \& Biological Archives, 3(4), 747-751.

Leung, H. W., Kuo, C. L., Yang, W. H., Lin, C. H., \& Lee, H. Z. (2006). Antioxidant enzymes activity involvement in luteolin-induced human lung squamous carcinoma $\mathrm{CH} 27$ cell apoptosis. Eur. J. Pharmacol., 534(1-3), 12-18.https://doi.org/10.1016/j.ejphar.2006.01.021

Leung, H. W., Wu, C. H., Lin, C. H., \& Lee, H. Z. (2005). Luteolin induced DNA damage leading to human lung squamous carcinoma CH27 cell apoptosis. Eur. J. Pharmacol., 508(1-3), 77-83.https://doi.org/10.1016/j.ejphar.2004.12.032

Lin, Y., Shi, R., Wang, X., \& Shen, H. M. (2008). Luteolin, a flavonoid with potential for cancer prevention and therapy. Curr. Cancer Drug Targets, 8(7), 634-646.https://doi.org/10.2174/156800908786241050

Makino, T., Ono, T., Muso, E., \& Honsa, G. (1998). Inhibitory effect of Perilla frutescens and its phenolic constituents on cultured murine mesangial cell proliferation. Planta Med., 64(6), 541-545.https://doi.org/10.1055/s-2006-957510

Mann, A., Abdulkadir, N. U., \& Muhammad, G. (2003). Medicinal and Economic plants of Nupe Land. Juber Evans Books.

Markaverich, B. M., \& Alejandro, M. A. (1997). Bioflavonoids, type II [3H] estradiol binding sites and prostatic cancer cell proliferation. Int. J. Oncol., 11(6), 1311-1319.

Manjamalai, A., \& Grace, V. M. B. (2004). Effect of essential oil of Tridax procumbens Linn on in-vivo antioxidant level in cancer model and in-vitro free radical scavenging activity. International Journal of Pharmaceutical Analysis, 37(10), 261-271.

Manjamalai, A., Kumar, M. M., \& Grace, V. M. B. (2012a). Essential Oil of Tridax procumbens L induces apoptosis and suppressed angiogenesis and lung metastasis of the B16F-10 cell line in C57BL/6 mice. Asian Pacific J Cancer Prev., 13(11), 5887-5895.https://doi.org/10.7314/APJCP.2012.13.11.5887

Manjamalai, A., Valavil, S., \& Grace, V. M. B. (2012b). Evaluation of essential oil of Tridax Procumbens L. for anti-microbial and anti-inflammatory activity. International Journal of Pharmacy and Pharmaceutical Science, 4(3), 0975-1491.

Martín-Quintal, Z., Moo-Puc, R., González-Salazar, F., Chan-Bacab, M. J., Torres-Tapia, L. W., Peraza-S, L. W., \& Torres-Sanchez, S. R. (2009). In vitroactivity of Tridax procumbens against promastigotes of Leishmania mexicana. J. Ethnopharmacol., 122(3), 463-467. https://doi.org/10.1016/j.jep.2009.01.037

Mitchell, S. A., \& Ahmad, M. H. (2006). A review of medicinal plant research at the University of West Indies, Jamaica, 1948-2001. West Indian Med. J., 55(4), 243-269. https://doi.org/10.1590/S0043-31442006000400008

National Center for Health Statistics. (2015). Health, United States, 2014; with special feature on adults aged 55-66. Hyattsville, MD. 201-202.

Nisha, M. H. (2011). Phytochemical and Biological investigation of Tridax procumbens leaves. Thesis report submitted to the Department of Pharmacy, East West University, Bangladesh, in partial fulfillment of the requirements for the degree in B. Pharm. ID: 2011-1-70-023. 
Nwanjo, H. U. (2008). Aqueous extract of Tridax procumbens leaves: Effect on lipid peroxidative stress and antioxidant status in chloroquine-induced hepatotoxicity in rats. Journal of Herbs, spices \& Medicinal Plants, 14(3-4), 154-165.https://doi.org/10.1080/10496470802598719

Olowokudejo, J. D., Kadiri, A. B., \& Travih, V. A. (2008). An ethnobotanical survey of herbal markets and medicinal plants in Lagos State of Nigeria. Ethnobotanical leaflets, 12, 851-865.

Pai, C., Kulkarni, U., Borde, M., Murali, S., Mrudula, P., \& Deshmukh, Y. (2011). Antibacterial activity of Tridax procumbens with special reference to nosocomial pathogens. British Journal of Pharmaceutical Research, 1(4), 164-173.https://doi.org/10.9734/BJPR/2011/763

Pardeshi, B. M., \& Bhiungade, V. (2016). Tridax procumbens: A medicinal gift of nature for healing diabetic wound. International Journal of Chemical and Physical Sciences IJCPS, 5, 107-112.

Pareek, H., Sharma, S., Khajja, B., Jain, K., \& Jain, G. C. (2009). Evaluation of hypoglycemic and anti-hyperglycemic potential of Tridax procumbens (Linn.). BMC Complementary and Alternative Medicine, 9(48). https://doi.org/10.1186/1472-6882-9-48

Patel, N. A., Vaidya, S. K., Kumar, S., Prasad, A. K., \& Bothara, S. B. (2014). Antioxidant and hepatoprotective activity of extracts of flowers of Tridax procumbens Linn, against Dgalectosamine induced hepatotoxicity in male Wister albino rats. IAJPR 4(49), 3712-3720.

Petchi, R. R., Parasuraman, S., \& Vijaya, C. (2013). Antidiabetic and antihyperlipidemic effects of an ethanolic extract of the whole plant of Tridax procumbens (Linn.) in streptozotocin-induced diabetic rats. Journal of Basic and Clinical Pharmacy, 4(4), 88-92.https://doi.org/10.4103/0976-0105.121655

Pettit, G. R., Hoard, M. S., Doubek, D. L., Schmidt, J. M., Pettit, R. K., Tackett, L. P., \& Chapuis, J. C. (1996). The cancer cell growth inhibitory constituents of Terminalia arjuna (Combretaceae). J. Ethnopharmacol., 53(2), 57-63.https://doi.org/10.1016/S0378-8741(96)01421-3

Policegoudra, R. S., Chattopadhyay, P., Aradhya, S. M., Shivaswamy, R., Sing, L., \& Veer, V. (2014). Inhibitory effect of Tridax procumbens against human skin pathogens. Journal of Herbal Medicine, 4(2), 83-88. https://doi.org/10.1016/j.hermed.2014.01.004

Pöll, E. (2005). Medicinal and Aromatic Plants of Guatemala and the Need for Their Conservation. Proc. WOCMAP III, Congress on Medicinal and Aromatic Plants 2: Conservation Cultivation \& Sustainable Use of MAPs Eds.: A. Jatisatienr, T. Paratasilpin, S. Elliott, V. Anusarnsunthorn, D. Wedge, L.E. Craker and Z.E. Gardner Acta Hort.,676, 167-170. https://doi.org/10.17660/ActaHortic.2005.676.21

Powell, M. A. (1965). Taxonomy of Tridax (Compositae). The New York Botanical Garden, 17, 47-96. https://doi.org/10.2307/2805391

Raghavan, T. S., \& Vinkatasubban, K. R. (1941). Contribution to the cytology of Tridax procumbens Linn.Department of Botany, Annamalai University, 85-110.

Rajendran, K., Balakrishnan, R., \& Chandrasekaran, S. (2003). Common medicinal plants and their utilization by villagers in East Coast districts of Tamilnadu. Journal of Economic and Taxonomic Botany, 27(3): 727-731.

Rao, P. S., Satelli, A., Moridani, M., Jenkins, M., \& Rao, U. S. (2012). Luteolin induces apoptosis in multidrug resistant cancer cells without affecting the drug transporter function: involvement of cell line-specific apoptotic mechanisms. Int. J. Cancer, 130(11), 2703-2714. https://doi.org/10.1002/ijc.26308

Ravikumar, V., Shivashangari, K. S., \& Devaki, T. (2005a). Effect of Tridax procumbens on liver antioxidant defense system during lipopolysaccharide-induced in D-galactosamine sensitized rats. Mole. Cell Biochem, 269(1-2), 131-136. https://doi.org/10.1007/s11010-005-3443-z

Ravikumar, V., Shivashangari, K. S., \& Devaki, T. (2005b). Hepatoprotective activity of Tridax procumbens against d-galactosamine-lipopolysaccharide-induced hepatitis in rats. J. Ethnopharmacol, 101(1-3), 55-60. doi:10.1016/j.jep.2005.03.019

Sailaja, B., Gharathi, K., \& Prasad, K. V. S. R. G. (2012). Role of Tridax procumbens Linn. In the management of experimentally induced urinary calculi and oxidative stress in rats. Indian Journal of Natural Products and Resources, 3(4), 535-540.

Salami, S., Salahdeen, H. M., Rahman, O. C., Murtala, B. A., \& Raji, Y. (2017). Oral administration of Tridax procumbens aqueous leaf extract attenuates reproductive function impairments in L-NAME induced hypertensive male rats. Middle East Fertility Society Journal. Article in press. Science Direct. http://dx.doi.org/10.1016/j.mefs.2017.03.001 
Saraf, S., \& Dixit, V. (1991). Hepatoprotective activity of Tridax procumbens - part II. Fitoterapia, 62, 534-536.

Saraf, S., Pathak, A., \& Dixit, V. K. (1990). Hair growth promoting activity of Tridax procumbens. Fitoterapia, 62(6), 495-498.

Sawant, S., Chine, V., Kalange, A., Joshi, P., Gawali, V., Praharaj, S. N., Jangme, C., \& Siddiqui, M. (2014). Evaluation of lyophilized extract of leaves of Tridax procumbens Linn. In rodent models of inflammatory and neuropathic pain. Orient Pharm. Exp. Med., 14(2), 163-167. https://doi.org/10.1007/s13596-013-0143-1

Sawant, R., \& Godghate, A. (2013). Preliminary phytochemical analysis of leaves of Tridax procumbens Linn. International Journal of Science, Environment and Technology, 2(3), 388-394.

Saxena, V., \& Albert, S. (2005). B-Sitosterol-3-O- $\beta$-D-xylopyranoside from the flowers of Tridax procumbensLinn. Journal of Chemical Sciences, 117(3), 263-266. https://doi.org/10.1007/BF02709296

Saxena, M., Mir, A. H., Sharma, M., Malla, M. Y., Qureshe, S., Mir, M. I., \& Chaturvedy, Y. (2013). Phytochemical screening and in-vitro antioxidant activity isolated bioactive compounds from Tridax procumbens Linn. Pak J. Biol. Sci., 16(24), 1971-1977. https://doi.org/10.3923/pjbs.2013.1971.1977

Seelinger, G., Merfort, I., Wolfle, U., \& Schempp, C. M. (2008). Anticarcinogenic effects of the flavonoid Luteolin. Molecules, 13(10), 2628-2651. https://doi.org/10.3390/molecules

Silambarasan, R., \& Ayyanar, M. (2015). An ethnobotanical study of medicinal plants in Palamai region of Eastern Ghats, India. Journal of Ethnopharmacology, 172, 162-178.https://doi.org/10.1016/j.jep.2015.05.046

Soladoye, M. O., Ikotun, T., Chukwuna, E. C., Ariwaodi, J. O., Ibhanesebor, G. A., Agbo-Adediran, O. A., \& Owolabi, S. M. (2013). Our plants, our heritage: Preliminary survey of some medicinal plant species of Southwestern University Nigeria Campus, Ogun State, Nigeria. Annals of Biological Research, 4(12), 27-34.

Solecki, R., \& Shanidar, I. V. (1975). A Neanderthal flower burial in Northern Iraq. Science, 190(4217), 880-881. https://doi.org/10.1126/science.190.4217.880

Sommer, A. (1995). Vitamin A deficiency and its consequences. A field guide to detection and control. World Health Organization. Third Edition. http://www.who.int/nutrition/publications/vad_consequences.pdf

Sonawane, A., Srivastava, R. S., Sanghavi, N., Malode, Y., \& Chavan, B. (2014). Anti-diabetic activity of Tridax procumbens. Journal of Scientific and Innovative Research, 3(2), 221-226.

Strasser, R. (2003). Rural health around the world: challenges and solutions. Oxford Journals, Family Practice, 20(4), 457-463. https://doi.org/10.1093/fampra/cmg422

Sureshkumar, J., Silambarasan, R., \& Ayyanar, M. (2017). An ethnopharmacological analysis of medicinal plants used by the Adiyan community in Wayanad district of Kerala, India. European Journal of Integrative Medicine, 12, 60-73. http://dx.doi.org/190.1016/j.eujim.2017.04.006

Taddei, A., \& Rosas-Romero, A. J. (2000). Bioactivity studies of extracts from Tridax procumbens. Phytomedicine, 7(3), 235-238. https://doi.org/10.1016/S0944-7113(00)80009-4

Tiwari, U., Rastogi, B., Singh, P., Saraf, K., \& Vyas, S. (2004). Immunomodulatory effects of aqueous extract of Tridax procumbens in experimental animals. Journal, 92(1), 113-119. https://doi.org/10.1016/j.jep.2004.02.001

Tu, S. H., Ho, C. T., Liu, M. F., Huang, C. S., Chang, H. W., Chang, C. H., Wu, C. H., \& Ho, Y. S. (2013). Luteolin sensitises drug-resistant human breast cancer cells to tamoxifen via de inhibition of cyclin E2 expression. Food Chemistry, 141(2), 1553-1561. https://doi.org/10.1016/j.foodchem.2013.04.077

U. S. Department of Agriculture. http://plants.usda.gov/core/profile?symbol=TRPR5. Retrieved March 20, 2015

Verma, R. K., \& Gupta, M. (1988). Lipid constituents of Tridax procumbens. Phytochemistry, 27(2), 459-463. https://doi.org/10.1016/0031-9422(88)83120-0

Vibrans, H. (2009). Tridax procumbens L. Retrieved March 24, 2016. http://www.conabio.gob.mx/malezasdemexico/asteraceae/tridax-procumbens/fichas/ficha.htm

Vishnu, P., Radhika, K., Siva, R., Ramchandra, M., Prameela, Y. A., \& Srinivas, R. (2011). Evaluation of anti-cancer activity of Tridax procumbens flower extracts on PC 3 cell lines. Pharmanest - An International Journal of Advances In Pharmaceutical Sciences, 2(1), 28-30. 
Wagh, S., \& Shinde, G. (2010). Antioxidant and hepatoprotective activity of Tridax procumbens Linn, against paracetamol induced hepatotoxicity in male albino rats. Advanced Studies in Biology, 2(3), 105-112.

Wagener, S., Volker, T., Spirit, S. D., Ernst, H., \& Stahl, W. (2012). 3,3'-Dihydroxyisorenioeratene and isorenieratene Prevent UV-induced DNA Damage in Human Skin. Free Radical Biology and Medicine, 53(3), 457-463. https://doi.org/10.1016/j.freeradbiomed.2012.05.022

WHO, World Health Organization. (2013). WHO traditional medicine strategy 2014-2023. Hong Kong SAR, China. ISBN 9789241506090.

Yabesh, J. E. M., Prabhu, S., \& Vijayakumar, S. (2014). An ethnobotanical study of medicinal plants used by traditional healers in silent valley of Kerala, India. Journal of Ethnopharmacology, 154, 774-789. https://doi.org/10.1016/j.jep.2014.05.004

Yamashita, N., \& Kawanishi, S. (2000). Distinct mechanisms of DNA damage in apoptosis induced by quercetin and luteolin. Free Radical Research, 33(5), 623-633.https://doi.org/10.1080/10715760000301141

\section{Copyrights}

Copyright for this article is retained by the author(s), with first publication rights granted to the journal.

This is an open-access article distributed under the terms and conditions of the Creative Commons Attribution license (http://creativecommons.org/licenses/by/4.0/). 